\title{
SOSIALISASI DAMPAK PERNIKAHAN DINI TERHADAP PERSEPSI DAN PEMAHAMAN SISWA PADA PROGRAM KULIAH KERJA PARTISIPATIF DARI RUMAH (KKP DR)
}

\author{
Soni Ariawan ${ }^{1}$, Baiq Imroatul Hasanah1, Desi Rusmana² \\ ${ }^{1}$ Universitas Islam Negeri Mataram, Mataram, Indonesia \\ ${ }^{2}$ Divisi Pendidikan Kesehatan Gelora Education Center, Mataram, Indonesia \\ *soniariawan@uinmataram.ac.id
}

\begin{abstract}
Abstrak: Pernikahan usia anak atau pernikahan dini masih menjadi masalah serius di Indonesia. Siswa sekolah sebagai generasi pada kelompok umur tersebut perlu memiliki pengetahuan yang komprehensif terkait penyebab dan akibat pernikahan usia anak sebagai upaya preventif. Kegiatan pengabdian ini penting dilakukan dengan tujuan mengubah persepsi siswa terhadap penyebab dan dampak dari pernikahan usia anak atau pernikahan dini tersebut. Kegiatan pengabdian ini dilakukan dengan metode sosialisasi dan bertempat di MA Nurul Haq Karang Bejelo Kabupaten Lombok Tengah. Sebanyak 50 peserta dari kelas XII mengikuti kegiatan tersebut. Namun karena keterbatasan waktu, hanya 30 orang yang mengisi pretest dan posttest melalui google form yang telah disediakan. Hasil analisis dari pretest dan posttest menunjukkan bahwa sebelum sosialisasi dilakukan, masih terdapat siswa yang memiliki persepsi positif dan persepsi relatif terhadap dampak pernikahan usia anak. Selain itu, mereka juga tidak mampu menyebutkan beberapa faktor penyebab dan dampak dari pernikahan usia anak ini. Setelah dilakukan sosialisasi, persepsi dan pemahaman mereka terhadap pernikahan dini berubah. Mereka meyakini pernikahan dini akan membawa kerugian dalam hal psikologis, biologis dan aspek kehidupan sosial. Mereka juga mampu menyebutkan berbagai faktor penyebab dan dampak dari pernikahan usia anak ini seperti dampak psikologis, biologis, budaya, sosial, ekonomi dan pendidikan. Hal ini menjukkan bahwa setelah diadakan sosialisasi, persepsi dan pemahaman siswa berubah.
\end{abstract}

Kata Kunci: pernikahan usia anak, persepsi positif, persepsi negatif, persepsi relatif

\begin{abstract}
Early marriage is still considered as one of the serious problems in Indonesia. School students need to have a comprehensive knowledge dealing with the causes and effects of early marriage as one of the preventive actions. This community service program is significantly crucial to change the students' perception on the causes and effects of early marriage. Socializations were held as the methodology of this program that took place at MA Nurul Haq Karang Bejelo Central Lombok District. It involved 50 students, however, due to the limitation of time, just 30 students participated in pretest and posttest developed in google form and distributed online. The tests found that there were some students who had positive and relative perception on the impacts of early marriage. In addition, they were also unable to mention various factors that cause early marriage and its impact. The perception and understanding have been changed after the socialization. They believe that early marriage would bring more harms than goods in terms of psychological, biological, and social aspect of life. Furthermore, the students were able to mention various factors that cause early marriage, such as lack of education, lack of family education as well as the misuse of technology and social media. This indicates that the students have already understood the material delivered in the socialization.
\end{abstract}

Keywords: early marriage, positive perception, negative perception, relative perception

\section{Pendahuluan}

Perkawinan usia anak atau lebih populer dikenal dengan terminologi pernikahan dini menjadi masalah krusial yang dihadapi bangsa Indonesia. Hal ini dikarenakan adanya sebuah tumpuan harapan pada pundak generasi muda yang menjadi penerus bangsa, namun banyak di 
antara mereka yang tidak bisa diharapkan karena berhenti di tengah jalan dengan memilih untuk menikah di usia anak. Tidak sedikit dari mereka yang tidak melanjutkan sekolah dan harus menanggung berbagai resiko akibat dari pilihan mereka tersebut. Hal yang terjadi kemudian bukan fokus untuk meraih cita-cita, tetapi harus hidup dengan realita yang tidak sedikit dari mereka pada akhirnya menyesalkan pilihan tersebut. Sementara itu, untuk mewujudkan generasi emas Indonesia tahun 2045 dibutuhkan generasi muda yang bukan hanya memiliki kualitas yang baik tetapi juga memiliki kepribadian yang baik, kemampuan berinteraksi sosial, memiliki karier serta secara fisik dan mental sehat (Qadafi \& Agustiningsih, 2021).

Data menunjukkan bahwa pada tahun 2018, 1 dari 9 anak perempuan menikah di Indonesia, sehingga diperkirakan ada sekitar 1.220 .900 perempuan umur 20-24 tahun yang menikah sebelum berusia 18 tahun di tahun 2018. Angka ini sangat besar, bahkan menempatkan Indonesia pada daftar 10 negara di dunia dengan angka perkawinan anak tertinggi di dunia (PUSKAPA, 2020). Statistik ini bisa dilihat sejak tahun 2017 dimana 1 dari 6 anak perempuan di Indonesia menikah sebelum usia 18 tahun, sehingga total keseluruhan terdapat sekitar 340.000 anak dan usia di bawah 15 tahun mencapai 50.000 anak per tahun (Romadoni, 2017). Bahkan pandemi Covid-19 turut memperparah keadaan karena angka perkawinan dini semakin tinggi. Direktorat Jenderal Badan Peradilan Agama merilis data sepanjang Januari-Juni 2020 dan menemukan bahwa terdapat 34.000 permohonan dispensasi kawin dan $97 \%$ dikabulkan serta $60 \%$ dari yang mengajukan tersebut adalah anak di bawah 18 tahun (Jayani, 2021). Angka ini jauh lebih tinggi dibandingkan tahun 2019 yang hanya mencapai 23.700.

Fakta-fakta di atas bisa dikaitkan dengan dampak Covid-19 yang sangat besar terutama pada sektor pendidikan yang mengharuskan anak-anak untuk belajar dari rumah. Minimnya aktivitas belajar secara formal di sekolah berakibat pada minimnya aktivitas belajar di rumah sehingga mereka memiliki keleluasaan dalam bergaul untuk menghabiskan waktu. Menurut data dari Kementrian PPA, kenaikan angka pernikahan dini di masa pandemi ini terjadi akibat faktor ekonomi, budaya dan dorongan keluarga yang menganggap menikahkan anaknya adalah jalan pintas untuk meringankan beban orang tua (DP3AP2KB, 2020). Oleh karena itu diperlukan langkah pereventif untuk membuka wawasan para remaja dan anak-anak untuk menghindari pernikahan dini. Mereka perlu diarahkan dan diberikan gambaran untuk fokus mengejar cita-cita dengan menuntaskan pendidikannya.

Berbagai penelitian dan kegiatan pengabdian masyarakat sebagai upaya untuk mencegah pekawinan usia anak telah dilakukan. Sebagian besar dari penelitian dan pengabdian tersebut menemukan berbagai macam faktor yang menjadi penyebab pernikahan usia anak ini. Sakdiyah \& Ningsih (2013) menyebutkan bahwa faktor utama yang menjadi pendorong menikah usia dini adalah faktor ekonomi, faktor diri sendiri, faktor pendidikan, dan faktor orang tua. Yanti, Hamidah, \& Wiwita, (2018) juga menyebutkan faktor yang relatif sama dengan penelitian sebelumnya yaitu faktor ekonomi, pendidikan, lingkungan dan tambahan satu faktor lagi yang tidak bisa diabaikan di era sekarang ini yaitu faktor media sosial. Berbagai platform media sosial saat ini semakin memudahkan para remaja untuk berinteraksi tanpa adanya kontrol dari orang tua. Terlebih lagi remaja masih memiliki sifat dan 
sikap yang tidak menentu, cenderung labil, karena masih dalam proses pembentukan dan pencarian jati diri. Mereka masih pada sebuah kondisi psikologis yang tidak menentu, antara ingin mandiri dan melepaskan diri dari orang tua, tetapi di satu sisi mereka masih belum memiliki kemampuan untuk mandiri baik dari segi psikologi, mental maupun materi (Mubasyaroh, 2016). Sejalan dengan penelitian ini, Essing, Purnomo, \& Susanti (2020) juga menyebutkan faktor perkembangan teknologi dan media sosial sebagai salah satu faktor yang ikut berkontribusi dalam meningkatkan angka perkawinan usia anak selain faktor pendidikan, budaya dan keluarga.

Dalam penelitian yang lain, faktor paling krusial yang menyebabkan pernikahan usia anak adalah faktor pendidikan anak tersebut dan orang tuanya (Deasy, 2017). Pendidikan dalam hal ini adalah minimnya pengetahuan anak terkait akibat atau dampak yang akan ditimbulkan oleh pernikahan dini. Disebutkan dalam sebuah penelitian bahwa remaja putri yang berpengetahuan rendah lebih rentan 2 atau 3 kali melakukan pernikahan dini dibandingkan dengan yang berpengetahuan tinggi (Handayani, 2014). Hal ini sejalan dengan penelitian yang dilakukan oleh Muntamah, Latifiani, \& Arifin (2019) dimana 77\% dari para remaja yang diteliti mengaku melakukan pernikahan dini karena ketidaktahuan penyebab dan akibtanya. Itulah kenapa pendidikan memiliki peranan yang sangat signifikan dalam mencegah pernikahan dini. Artinya, jika mereka melanjutkan sekolah bahkan sampai jenjang perguruan tinggi, akan sangat sedikit sekali kemungkinan untuk melakukan pernikahan dini karena mereka akan fokus untuk menyelesaikan studi. Selain faktor pendidikan anak, latar belakang pendidikan orang tua juga sangat berpengaruh terhadap angka pernikahan ini. Orang tua yang tidak mampu memaksimalkan pendidikan keluarga tentu akan menyebabkan anak sebagai anggota keluarga kehilangan momentum untuk belajar. Orang tua memiliki peranan komunikasi keluarga yang sangat penting dalam mengedukasi anak-anaknya (Desiyanti, 2015) sehingga mereka tidak terjebak pada pergaulan bebas yang tidak terkontrol.

Pernikahan usia anak akan memberikan dampak yang sangat serius terhadap psikologi, mental maupun fisik anak tersebut. Ditinjau dari segi kesehatan, perkawinan usia anak akan meningkatkan resiko kehamilan karena organ reproduksinya belum siap. Data yang dirilis oleh Badan Pusat Statistik (2017) menyebutkan bahwa perempuan berusia 20-24 tahun yang menikah di usia kurang dari 18 tahun lebih banyak ditolong oleh tenaga kesehatan pada saat persalinan. Bahkan jumlah mereka lebih dari $92 \%$ dibandingkan mereka yang menikah di atas 18 tahun. Ditinjau dari segi pendidikan, mereka yang melakukan pernikahan dini banyak mengambil konsekuensi putus sekolah. Hal ini berarti mereka kehilangan kesempatan untuk melanjutkan pendidikan ke jenjang yang lebih tinggi. Mereka meninggalkan pendidikan formal dan akan semakin sulit untuk mengakses lapangan pekerjaan (Afriani \& Mufdlilah, 2016). Hal ini kemudian akan berdampak lagi terhadap pola pikir mereka dalam menjalani hidup dan kehidupan ini. Emosi mereka cenderung tidak stabil dalam menyelesaikan setiap persoalan sehingga rawan terjadi konflik dan berujung pada perceraian. Data BPS tahun 2017 juga menjelaskan bahwa tingkat perceraian perempuan usia 20-24 tahun yang menikah sebelum usia 18 tahun cenderung meningkat. Selain dampak terhadap pendidikan, pernikahan usia anak tentu juga akan berdampak terhadap mental atau psikologi, serta lingkungan sosial 
dimana mereka seringkali dinilai akan gagal dalam membina rumah tangga. Asumsi ini sedikit tidak akan memengaruhi sikap dan mental mereka dalam membina rumah tangga karena tidak bisa dipungkiri bahwa tingkat kematangan emosi dan kedewasaan menghadapi masalah juga berbanding lurus dengan usia dan tingkat pendidikan.

Dengan demikian, diperlukan pembinaan dan penyulusan terkait dampak dari pernikahan usia anak, baik dari instansi pemerintahan, swasta maupun gerakan-gerakan pemuda dan mahasiswa. Peran aktif pembinaan dari tokoh masyarakat dan tokoh agama juga sangat diperlukan sebagai upaya untuk mencegah terjadinya pernikahan dini dengan menggalakkan sosialisasi tentang UU Perkawinan No. 1 Tahun 1974 (Sakdiyah \& Ningsih, 2013). Di samping itu, sosialisasi pada remaja, masyarakat dan orang tua juga akan memberikan wawasan terhadap bahaya pernikahan dini baik dari segi kesehatan, mental, pendidikan dan sosial sehingga perlu dilakukan oleh pemerintah dan didukung oleh lembagalembaga resmi (Indrianingsih, Nurafifah, \& Januarti, 2020). Inilah yang menjadi latar belakang dilakukan pengabdian ini sebagai upaya untuk memberikan wawasan serta pengetahuan akan bahaya pernikahan usia anak kepada para remaja.

Kegiatan ini merupakan salah satu program Kuliah Kerja Partisipasti dari Rumah (KKP-DR) yang dilakukan oleh mahasiswa Universitas Islam Negeri Mataram. Sosialisasi dengan konsep yang terukur dirumuskan untuk mengetahui persepsi siswa terhadap pernikahan usia anak atau pernikahan dini. Hasilnya tidak berpusat pada jumlah peserta, tetapi lebih kepada representasinya. Dalam kegiatan ini, sekitar 50 siswa mengikuti sosialisasi yang dilakukan secara terbuka, namun karena keterbatasan waktu, hanya 30 dari mereka dijadikan sampel untuk mengecek tingkat pemahaman dan persepsi mereka terhadap pernikahan dini. Maka dilakukan pretest dan posttest secara online. Kegiatan pengabdian ini dilaksanakan di MA Nurul Haq Karang Bejelo Kabupaten Lombok Tengah, Nusa Tenggara Barat dengan tujuan untuk mengubah persepsi siswa terhadap penyebab dan dampak dari pernikahan usia anak atau pernikahan dini yang masih menjadi masalah besar di Indonesia terkait pernikahan usia anak.

\section{Metode}

Ada beberapa pendekatan dalam pengabdian masyarakat, diantaranya adalah Participatory Action Research (PAR), Asset-Based Community Development (ABCD) dan Community-Based Research (CBR) (LP2M, 2019). Pendekatan PAR menekankan pada upaya aksi pengabdian secara partisipatif dengan berbasis pada riset terlebih dahulu agar sasaran pengabdian tepat dan efektif. Sementara itu, pendekatan $A B C D$ fokus pada upaya memposisikan masyarakat sebagai mitra dan menggali potensi atau asset dalam konteks kehidupan masyarakat sebagai landasan dalam melakukan pengabdian. Pendekatan CBR lebih cenderung kepada melibatkan kelompok organisasi/masyarakat dalam melakukan kegiatan pengabdian. Kegiatan pengabdian ini menggunakan pendekatan PAR dimana kegiatan dimulai dengan melakukan riset terlebih dahulu dalam bentuk pretest untuk mengetahui tingkat pemahaman peserta. Hasil pretest ini kemudian digunakan sebagai basis data untuk mendesain materi sosialisasi agar mendapatkan hasil yang diinginkan. 
Secara lebih spesifik, kegiatan pengabdian ini dilakukan dengan metode sosialisasi secara terbuka yang dihadiri oleh 50 mahasiswa. Sosialisasi merupakan salah satu sarana untuk memengaruhi kepribadian seseorang dan tepat sekali dilakukan jika bertujuan agar memengaruhi orang tersebut untuk mengambil peran masing-masing (Murtani, 2019). Kegiatan tersebut dilakukan dengan metode ceramah dan diskusi dimana pemateri menjelaskan dampak serta akibat dari pernikahan usia anak dan diikuti oleh kegiatan diskusi atau tanya jawab. Ada beberapa tahapan yang dilakukan dalam kegiatan pengabdian kepada masyarakat ini. Tahapan dimulai dari pemetaan potensi dan masalah, persiapan sosialisasi, kegiatan sosilaisasi itu sendiri. Tahapan-tahapan ini dibuat agar kegiatan terencana dengan baik dan meminimalisir kekurangan saat pelaksanaan.

1. Pemetaan Potensi dan Masalah

Pemetaan potensi dan masalah dilakukan untuk mendapatkan gambaran utuh terkait lokasi kegaitan pengabdian kepada masyarakat. Selain data dan informasi dari desa, kami melakukan koordinasi dengan pihak sekolah sehingga mendapatkan beberapa kesimpulan. Pertama, angka pernikahan usia anak dan perceraian pasangan muda relatif tinggi di desa tersebut. Kedua, sebagian besar dari para siswa tidak mengetahui secara jelas dampak yang akan ditimbulkan oleh pernikahan usia anak atau lebih dikenal dengan pernikahan dini, sehingga beberapa di antara mereka ada yang putus sekolah karena menikah. MA Nurul Haq Karang Bejelo dipilih menjadi lokasi karena rekomendasi dari pemerintah desa dan kami melihat sebuah potensi dimana madrasah tersebut memiliki siswa yang banyak sehingga materi sosialisasi yang diberikan akan diterima oleh mereka. Harapannya adalah mereka bisa meneruskan informasi atau materi tersebut ke temannya yang lain. Potensi lain yang bisa dimaksimalkan adalah peranan madrasah dalam meluruskan pemahaman budaya yang masih kental dengan merariq kodeq (menikah usia anak) yang masih terjadi di beberapa wilayah di pulau Lombok sehingga mereka tidak terjebak pada hal tersebut (Husnan, 2018).

2. Persiapan Sosialisasi Pernikahan Usia Anak

Persiapan sosialisasi dimulai dari tahapan penentuan narasumber dan penyusun instrumen pretest dan posttest serta melakukan analisis terhadap hasil tes tersebut. Tahap persiapan yang memakan waktu cukup lama adalah koordinasi dengan sekolah/madrasah untuk mendapatkan jadwal yang tepat sehingga tidak bertabrakan dengan aktivitas pembelajaran di sekolah. Materi dan instrumen tes disusun secara terstruktur dan terukur agar memudahkan dalam tahap evaluasi tingkat keberhasilan. Pretest diberikan sebelum sosialisasi dilakukan untuk mengetahui persepsi dan pemahaman siswa terkait penyebab dan dampak pernikahan usia anak. Hal ini penting dilakukan untuk mengukur pemahaman awal siswa serta memudahkan pemateri untuk menyusun materi yang sesuai dengan tingkat pemahaman tersebut. Sementara itu, posttest dilakukan setelah sosialisasi untuk mengetahui perubahan persepsi dan pemahaman siswa terhadap pernikahan usia anak. Karena keterbatasan waktu, maka pretest dan postetest dilakukan secara online melalui google form. Kami menawarkan kepada siswa untuk bergabung di grup WhatsApp untuk memudahkan koordinasi. Link pengisian google form disebarkan melalui grup tersebut. Ada 30 orang siswa kelas XII yang bergabung dalam grup WhatsApp dan berpartisipasi dalam pretest dan 
posttest. Menurut penulis,30 orang ini bisa menjadi representasi siswa yang lain karena dari hasil pretest dan posttest tercermin adanya konsistensi data yang bisa dijadikan sebagai representasi dari persepsi dan pemahaman siswa di sekolah/madrasah tersebut.

3. Kegiatan Sosialisasi Pencegahan Pernikahan Usia Anak

Kegiatan sosialisasi dilakukan dengan metode ceramah dimana pemateri memberikan informasi dan pengetahuan terkait penyebab dan dampak pernikahan usia anak. Pemateri menjelaskan aspek kesehatan, aspek pendidikan, aspek sosial keagamaan, aspek psikologi dan aspek lain yang menjadi penyebab serta dampak dari pernikahan usia anak. Durasi sosialisasi adalah 1 jam pelajaran dengan teknis terpusat dimana siswa berkumpul di halaman sekolah/madrasah dan pemateri memaparkan materinya dengan metode ceramah. Setelah materi tersampaikan, dibuka sesi diskusi atau tanya jawab.

\section{Hasil dan Pembahasan}

\section{Peserta Sosialisasi Pencegahan Pernikahan Dini}

Peserta pada kegiatan sosialisasi ini adalah siswa dan siswi kelas XII di MA Nurul Haq Karang Bejelo yang berjumlah sekitar 50 orang. Dalam pelaksanaan evaluasi berupa pretest dan posttest, ada 30 orang siswa yang berpartisipasi. Gambar di bawah ini merupakan dokumentasi sosialisasi dimana para siswa diberikan arahan untuk mengisi pretest, mengikuti materi sosialisasi dengan baik dan mengisi posttest untuk mengukur tingkat pemahaman mereka terhadap dampak pernikahan dini. Data siswa yang mengikuti tes tersebut dapat dilihat pada Tabel 1 di bawah ini.

Tabel 1. Data Peserta Mengikuti Pretest dan Posttest

\begin{tabular}{ccc}
\hline Jenis Kelamin & Umur & Jumlah \\
\hline Laki-laki & 19 & 8 \\
\hline \multirow{3}{*}{ Perempuan } & 20 & 2 \\
\cline { 2 - 3 } & 16 & 5 \\
\cline { 2 - 3 } & 18 & 5 \\
\cline { 2 - 3 } & 17 & 10 \\
\hline
\end{tabular}
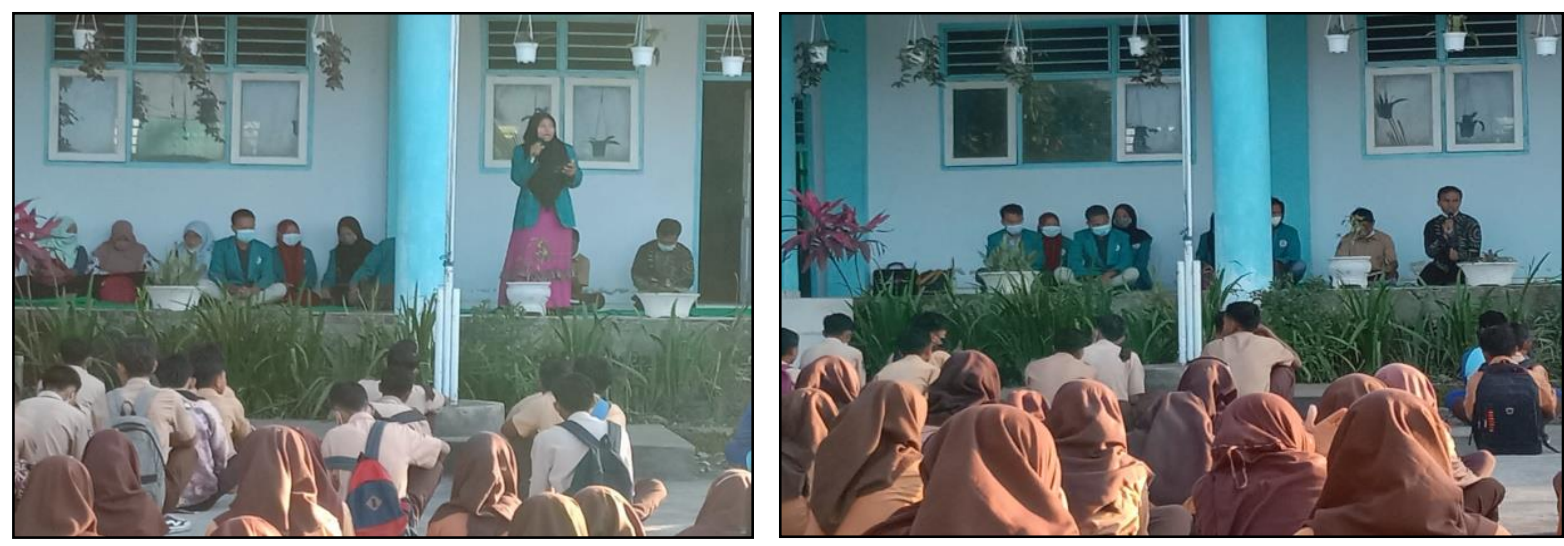

Gambar 1. Sosialisasi pencegahan pernikahan dini 


\section{Persepsi dan Pemahaman Siswa terhadap Pernikahan Dini Sebelum Sosialisasi}

Dari hasil tes sebelum dilakukan sosialisasi (pretest), dapat ditemukan bahwa masih ada siswa yang memiliki persepsi positif/baik terhadap pernikahan usia anak. Ada $10 \%$ siswa yang masih berasumsi bahwa pernikahan usia anak bernilai positif. Selain itu, ada 10\% siswa juga yang memiliki persepsi relatif terhadap pernikahan usia anak sebagaimana yang ditampilkan dalam Tabel 2. Persepsi relatif berarti mereka menganggap bahwa pernikahan usia anak adalah sebuah hal yang buruk dan berbahaya, namun di satu sisi mereka menganggap hal tersebut sebagai sebuah solusi dibandingkan hal lebih buruk lainnya misalnya hamil di luar nikah dll. Hal ini berarti masih terdapat sebuah kekeliruan persepsi dan pemahaman siswa terhadap pernikahan usia anak. Data pada Tabel 2 juga menunjukkan bahwa sebagian besar siswa (80\%) masih menganggap bahwa pernikahan dini adalah sebuah hal yang buruk dan memiliki asumsi bahwa penyebab utamanya adalah faktor ekonomi, hamil di luar nikah dan pergaulan. Faktorfaktor penyebab ini sesuai dengan hasil penelitian Sakdiyah \& Ningsih (2013) dengan tambahan beberapa faktor berupa kurangnya kasih sayang orang tua dan keterpaksaan.

Selain itu, hal menarik yang bisa dianalisis dari jawaban responden adalah sebagian besar dari mereka mereka memiliki pendapat bahwa hamil di luar nikah dan faktor ekonomi yang menjadi penyebab utama pernikahan dini. Jawaban ini bisa diartikan bahwa mereka sudah memiliki spekulasi dan asosiasi bahwa pernikahan usia anak atau pernikahan dini identik dengan kecelakaan atau hamil di luar nikah adanya keterpaksaan karena alasan ekonomi. Hal ini bisa menjadi alasan mendasar responden yang memilik persepsi relatif dimana pernikahan usia anak menjadi solusi bagi mereka yang hamil di luar nikah atau terdesak karena himpitan ekonomi. Asumsi dasar ini tentu sangat berbahaya jika dijadikan pembenaran untuk menikah di usia anak. Bagaimanapun juga, pernikahan usia anak akan memiliki dampak dan risiko yang harus ditanggung oleh mereka. Dalam hal ini, jawaban responden sebagaian besar sama, yaitu pernikahan usia anak akan berujung pada perceraian dan pengangguran. Dari jawaban ini, dapat dianalisis bahwa mereka tidak memiliki pengetahuan yang cukup untuk mengelaborasi penyebab serta dampak yang akan ditumbulkan oleh pernikahan usia anak. Faktor ketidaktahuan ini menjadi salah satu faktor utama penyebab pernikahan usia anak sebagaimana penelitian yang ditemukan oleh Muntamah et al.,(2019). Hasil dari pretest yang dimaksud di atas bisa dilihat dengan jelas pada Tabel 2 di bawah ini.

Tabel 2. Hasil pretest persepsi siswa terhadap penyebab pernikahan dini

\begin{tabular}{clcc}
\hline Persepsi & Penyebab & Frekuensi & Persentase \\
\hline \multirow{3}{*}{ Buruk } & Faktor ekonomi & 9 & $30 \%$ \\
\cline { 2 - 4 } & Hamil di luar nikah & 9 & $30 \%$ \\
\cline { 2 - 4 } & Pergaulan & 6 & $20 \%$ \\
\hline \multirow{2}{*}{ Relatif } & Hamil di luar nikah & 2 & $7 \%$ \\
\cline { 2 - 4 } & Terpaksa & 1 & $3 \%$ \\
\hline \multirow{3}{*}{ Baik } & $\begin{array}{l}\text { Kurang kasih sayang } \\
\text { orang tua }\end{array}$ & 2 & $7 \%$ \\
\cline { 2 - 4 } & Faktor ekonomi & 1 & $3 \%$ \\
\hline
\end{tabular}


Adapun persepsi responden terhadap dampak yang akan ditimbulkan oleh pernikahan dini dapat dilihat pada Tabel 3 berikut ini. 80\% dari responden memiliki keyakinan bahwa pernikahan dini akan menimbulkan dampak yang buruk yaitu pernikahan yang tidak resmi, perceraian dan pertengkaran di ruumah tangga. 50\% dari responden memiliki keyakinan bahwa perceraian merupakan dampak paling buruk akibat dari pernikahan dini. Selain itu, dapat dilihat juga dari tabel di bawah ini bahwa responden yang tadinya memiliki persepsi relati dan buruk, juga memiliki keyakinan bahwa sebenarnya pernikahan dini akan menimbulkan dampak buruk seperti perceraian dan pengangguran.

Tabel 3. Hasil pretest persepsi siswa terhadap dampak pernikahan dini

\begin{tabular}{llcc}
\hline Persepsi & Dampak & Frekuensi & Persentase \\
\hline \multirow{3}{*}{ Buruk } & Nikah tidak resmi & 6 & $20 \%$ \\
\cline { 2 - 4 } & Perceraian & 15 & $50 \%$ \\
\cline { 2 - 4 } & Bertengkar & 3 & $10 \%$ \\
\hline \multirow{2}{*}{ Relatif } & Perceraian & 2 & $7 \%$ \\
\cline { 2 - 4 } & Pengangguran & 1 & $3 \%$ \\
\hline \multirow{2}{*}{ Baik } & Perceraian & 3 & $10 \%$ \\
\hline & Total & 30 & $100 \%$ \\
\hline
\end{tabular}

\section{Persepsi dan Pemahaman Siswa terhadap Pernikahan Dini Setelah Sosialisasi}

Setelah kegiatan sosialisasi, dilakukan evaluasi melalui instrumen berupa tes (posttest). Ditemukan bahwa semua siswa memiliki persepsi buruk terhadap pernikahan dini. Hal ini menujukkan bahwa mereka sudah memahami penyebab dan dampak yang akan ditimbulkan oleh pernikahan dini sehingga mereka yang tadinya masih memiliki persepsi baik atau relatif berubah menjadi buruk. Menurut mereka, faktor terbesar yang menjadi penyebab pernikahan dini adalah pergaulan bebas, $27 \%$, kurangnya kontrol dari keluarga dan pengaruh buruk media sosial, $20 \%$, dan minimnya pendidikan, $13 \%$. Data lebih rinci bisa dilihat pada Tabel 4 di bawah ini.

Selain itu, dilihat dari jawaban mereka terkait penyebab pernikahan dini, mereka memiliki pemahaman yang komprehensif. Mereka tidak hanya menyebutkan faktor ekonomi, tetapi terdapat faktor budaya, pendidikan dan asuhan keluarga. Pendidikan, baik anak dan orang tua, memainkan peranan yang sangat penting dalam upaya mencegah terjadinnya pernikahan usia anak (Deasy, 2017; Desiyanti, 2015). Melalui pendidikan, anak-anak akan dibekali bukan hanya pengetahuan, tetapi juga daya pikir kritis sehingga mereka tidak cepat memutuskan atau mengambil sebuah langkah sebelum melakukan analisis dampak baik dan buruknya. Kemampuan ini akan menjadi tameng mereka agar terhindar dari pernikahan usia anak.

Faktor lain yang juga disebutkan oleh responden dalam posttest adalah media dan teknologi. Perkembangan teknologi yang semakin canggih serta memungkinkan para penggunanya untuk berinteraksi melalui video menjadi semakin tidak bisa dikontrol. Banyak di antara mereka berkenalan dengan berbagai macam karakter pengguna media sosial yang lain dan memulai pendekatan dari sana. Padahal, mereka tidak akan mungkin bisa saling kenal 
mengenal satu sama lain baik sifat, karakter maupun latar belakangnya tanpa berinteraksi secara langsung. Realita ini sama dengan hasil penelitian dari Yanti et al. (2018) dan Essing et al. (2020) bahwa perkembangan teknologi dan media sosial sebagai salah satu faktor yang ikut berkontribusi dalam meningkatkan angka perkawinan usia anak selain faktor pendidikan, budaya dan keluarga.

Tabel 4. Hasil posttest persepsi siswa terhadap penyebab pernikahan usia anak

\begin{tabular}{llcc}
\hline Persepsi & Penyebab & Frekuensi & Persentase \\
\hline \multirow{5}{*}{ Buruk } & Hamil di luar nikah & 1 & $3 \%$ \\
\cline { 2 - 4 } & Pergaulan bebas & 8 & $27 \%$ \\
\cline { 2 - 4 } & Budaya & 1 & $3 \%$ \\
\cline { 2 - 4 } & Kurang kontrol keluarga & 6 & $20 \%$ \\
\cline { 2 - 4 } & Media sosial & 6 & $20 \%$ \\
\cline { 2 - 4 } & Minimnya pendidikan & 4 & $13 \%$ \\
\cline { 2 - 4 } & Teknologi & 2 & $7 \%$ \\
\cline { 2 - 4 } & Faktor ekonomi & 30 & $100 \%$ \\
\hline \multicolumn{1}{c}{ Total } & & \\
\hline
\end{tabular}

Dari jawaban mereka tentang dampak pernikahan dini atau usia anak, sebagian besar responden, 33\%, meyakini bahwa perceraian di usia muda merupakan dampak terburuk yang diakibatkan oleh pernikahan dini. Di samping itu, dari Tabel 5 di bawah ini, dapat dilihat bahwa responden juga sudah memahami secara utuh penyebab dan dampak pernikahan usia anak tersebut. Mereka tidak hanya menyebutkan perceraian sebagai akibatnya, tetapi juga sudah mengarah kepada dampak ekonomi, psikologi, sosial dan kesehatan bahkan aspek mental baik pada pihak pria maupun wanita (Astuti, 2017). Dari segi psikologi misalnya, akan terjadi ganguan mental yang bisa mengakibatkan stress dan gangguan jiwa akibat terjadi perceraian. Dari segi biologi, ketidakmatangan organ reproduksi akan mengakibatkan kecacatan pada anak atau kematian pada ibu dan bayi. Hal ini menunjukkan bahwa sosialisasi yang dilakukan diterima dengan baik oleh siswa. Selain itu, sebagian besar responden juga berkeyakinan bahwa perceraian di usia muda akan menjadi dampat buruk yang akan ditimbulkan oleh pernikahan dini.

Tabel 5. Hasil posttest persepsi siswa terhadap dampak pernikahan usia anak

\begin{tabular}{llcc}
\hline Persepsi & Dampak & Frekuensi & Persentase \\
\hline \multirow{5}{*}{ Buruk } & Perekonomian susah & 4 & $13 \%$ \\
\cline { 2 - 4 } & Perceraian muda & 10 & $33 \%$ \\
\cline { 2 - 4 } & Kematian & 2 & $7 \%$ \\
\cline { 2 - 4 } & Ganguan kejiwaan & 3 & $10 \%$ \\
\cline { 2 - 4 } & Kematian & 3 & $10 \%$ \\
\cline { 2 - 4 } & KDRT & 4 & $13 \%$ \\
\cline { 2 - 4 } & Ketidaksiapan organ biologis & 4 & $13 \%$ \\
\hline \multicolumn{2}{c}{ Total } & 30 & $100 \%$ \\
\hline
\end{tabular}




\section{Kesimpulan}

Hasil dari kegiatan pengabdian ini menunjukkan bahwa terjadi perubahan persepsi responden dimana hasil pretest menunjukkan bahwa masih ada responden yang menganggap pernikahan dini baik atau relatif. Namun, hasil posttest menunjukkan bahwa semua responden memiliki persepsi bahwa pernikahan usia anak atau pernikahan dini adalah sesuatu yang buruk. Hasil posttest juga menunjukkan bahwa responden memahami berbagai dampak yang akan terjadi akibat dari pernikahan dini. Oleh karena itu, berbagai solusi harus ditempuh untuk mencegeh pernikahan dini. Salah satunya adalah ruang diskusi antara anak dan orang tua harus terbuka. Hal ini menjadi sangat penting agar anak merasa nyaman menceritakan berbagai permasalahannya kepada orang tua sehingga anak-anak akan mendapatkan pengetahuan dan pengalaman bukan hanya dari bangku sekolah, tetapi juga dari keluarga. Hasil evaluasi dari kegiatan pengabdian kepada masyarakat ini juga telah menunjukkan bahwa sosialisasi penting untuk dilakukan oleh semua pihak, baik pemerintah, tokoh agama, tokoh masyarakat, sekolah dan perguruan tinggi serta kelompok pemuda atau masyarakat yang peduli dengan upaya pencegahan pernikahan dini. Sosialisasi memiliki peran sebagai sebuah tambahan ilmu pengetahuan bagi mereka. Dibutuhkan pihak luar, selain dari sekolah atau keluarga, untuk menginjeksikan pengetahuan akan penyebab dan dampak menikah di usia dini. Kegiatan pengabdian masyarakat dalam bentuk sosialisasi untuk mengubah persepsi dan pemahaman siswa ini menjadi salah satu bentuk konkret dari aksi preventif pencegahan pernikahan usia anak. Hasil dari kegiatan pengabdian ini sekaligus menjadi rekomendasi kepada stakeholder baik pemerintah maupun sekolah agar melakukan upaya-upaya yang serius sebagai aksi bersama untuk mencegah pernikahan dini.

\section{Referensi}

Afriani, R., \& Mufdlilah, M. (2016). Analisis Dampak Pernikahan Dini Pada Remaja Putri Di Desa Sidoluhur Kecamatan Godean Yogyakarta [Other, Universitas 'Aisyiyah Yogyakarta]. http://lib.unisayogya.ac.id

Astuti, A. M. (2017). Sosialisasi dampak pernikahan dini terhadap kesehatan reproduksi Desa Sembung Kecamatan narmada Kabupaten Lombok Barat. Transformasi: Jurnal Pengabdian Masyarakat, 13(1), 92-108. https://doi.org/10.20414/transformasi.v13i1.1983

Badan Pusat Statistik. (2017). Perkawinan Usia Anak di Indonesia (2013 dan 2015). Badan Pusat Statistik.

Deasy, A. (2017). Faktor Dominan Penyebab Pernikahan Usia Dini di Kecamatan Banjarmasin Selatan Tahun 2010-2014. JPG (Jurnal Pendidikan Geografi), 3(5), 15-21.

Desiyanti, I. W. (2015). Faktor-Faktor yang Berhubungan Terhadap Pernikahan Dini Pada Pasangan Usia Subur di Kecamatan Mapanget Kota Manado. JIKMU, 5(3), Article 3. https://ejournal.unsrat.ac.id/index.php/jikmu/article/view/7443

DP3AP2KB. (2020, September 9). Dampak Pandemi Covid-19 terhadap Peningkatan Angka Kekerasan Anak dan Pernikahan Dini di Provinsi NTB. Dinas Pemberdayaan Perempuan Perlindungan Anak Pengendalian Penduduk dan Keluarga Berencana Provinsi Nusa Tenggara Barat. https://dp3ap2kb.ntbprov.go.id/2020/09/10/dampak-pandemi-covid-19-terhadappeningkatan-angka-kekerasan-anak-dan-pernikahan-dini-di-provinsi-ntb/

Essing, S. E., Purnomo, D., \& Susanti, A. T. (2020). Analisis Penyebab Perkawinan Usia Anak di Dusun Ngronggo Kelurahan Kumpulrejo Salatiga. Cakrawala Jurnal Penelitian Sosial, 9(2), 185-204. 
Handayani, E. Y. (2014). Faktor-Faktor Yang Berhubungan Dengan Pernikahan Usia Dini Pada Remaja Putri Di Kecamatan Tambusai Utara Kabupaten Rokan Hulu. Jurnal Martenity and Neonatal, 1(5), 200-206.

Husnan, H. (2018). Peran Madrasah dalam Pembelajaran Fiqh terhadap Tradisi Merariq Faktor Pendukung Dipertahankannya oleh Masyarakat Kekait Kecamatan Gunungsari Lombok Barat (Studi Kasus Peranan Madrasah di Desa Terpencil). Ibtida'iy: Jurnal Prodi PGMI, 3(1), 21-37. https://doi.org/10.31764/ibtidaiy.v3i1.1053

Indrianingsih, I., Nurafifah, F., \& Januarti, L. (2020). Analisis Dampak Pernikahan Usia Dini dan Upaya Pencegahan di Desa Janapria. Jurnal Warta Desa (JWD), 2(1), 16-26. https://doi.org/10.29303/jwd.v2i1.88

Jayani, D. H. (2021). Wabah Pernikahan Dini di Tengah Pandemi dan Dampak Buruknya-Analisis Data Katadata. https://katadata.co.id/muhammadridhoi/analisisdata/5ff7cb5cdf279/wabahpernikahan-dini-di-tengah-pandemi-dan-dampak-buruknya

Mubasyaroh, M. (2016). Analisis Faktor Penyebab Pernikahan Dini dan Dampaknya. YUDISIA: Jurnal Pemikiran Hukum Dan Hukum Islam, 72), 385-411. https://doi.org/10.21043/yudisia.v7i2.2161

Muntamah, A. L., Latifiani, D., \& Arifin, R. (2019). Pernikahan Dini di Indonesia: Faktor dan Peran Pemerintah (Perspektif Penegakan Dan Perlindungan Hukum Bagi Anak). Widya Yuridika: Jurnal Hukum, 2(1), 1-12. https://doi.org/10.31328/wy.v2i1.823

Murtani, A. (2019). Sosialisasi Gerakan Menabung. SINDIMAS, 1(1), 279-283. https://doi.org/10.30700/sm.v1i1.585

PUSKAPA. (2020). Pencegahan Perkawinan Anak: Percepatan yang Tidak Bisa Ditunda. PUSKAPA. https://puskapa.org/publikasi/881/

Qadafi, M., \& Agustiningsih, N. (2021). Pendidikan Kesehatan Reproduksi Untuk Mencegah Merariq Kodeq (Pernikahan Dini) di Ma Al-Islahuddiny. Jurnal PkM Pengabdian kepada Masyarakat, 4(3), 222-232. https://doi.org/10.30998/jurnalpkm.v4i3.6427

Romadoni, hmad. (2017). UNICEF Soroti Pernikahan Dini di Indonesia-News Liputan6.com. https://www.liputan6.com/news/read/2870119/unicef-soroti-pernikahan-dini-di-indonesia

Sakdiyah, H., \& Ningsih, K. (2013). Mencegah pernikahan dini untuk membentuk generasi berkualitas. 26, 20.

LP2M. (2019). Pedoman Pengabdian Kepada Masyarakat dan Kuliah Kerja Nyata. Jambi: Lembaga Penelitian dan Pengabdian kepada Masyarakat (LP2M) UIN Sultan Thaha Saifuddin Jambi.

Yanti, Y., Hamidah, H., \& Wiwita, W. (2018). Analisis Faktor Penyebab dan Dampak Pernikahan Dini di Kecamatan Kandis Kabupaten Siak. JURNAL IBU DAN ANAK, 6(2), 96-103. https://doi.org/10.36929/jia.v6i2.94 